\title{
Mensagem do Presidente do SIF
}

Minas Gerais já se afirmou como um pólo de estudo e tratamento das doenças venosas. Os últimos congressos que a SBACV-MG realizou foram executados com êxito e com grande proveito dos inúmeros colegas que acorreram de todo o país.

Foi um grande prazer encontrar amigos e fazer novos, em cada um dos nossos congressos e simpósios.

Nossos eventos contam com o apoio institucional e de inúmeras empresas que atuam no nosso setor. Saímos engrandecidos com a participação de todos.

Nossos convidados nacionais e internacionais corresponderam às nossas expectativas trazendo-nos informações sobre tecnologias modernas e ponderando sobre nossos conceitos clássicos.

Agora anunciamos o nosso próximo evento: o SIF 2013, SIMPOSIO INTERNACIONAL DE FLEBOLOGIA DA SBACV-MG que se dará nos dias 21, 22 e 23 de Março de 2013 no Hotel Ourominas - Belo Horizonte. Desta vez, entre os nomes internacionais convidamos Paul Pittaluga, Gilles Gachet e Charles Zarca, da França e Jorge Segura da Argentina. O primeiro já esteve conosco em outro simpósio, e é conhecido por seus trabalhos de divulgação de nova abordagem cirúrgica para corrigir a degeneração da rede venosa de mmii. Ele diz que a propedêutica e a terapêutica modernas levaram-nos a refletir muito sobre o papel das veias tributárias de safena, desde o tornozelo até a junção safeno-femoral. Dr Gachet é o presidente do Club-mousse.com e um dos pioneiros da escleroterapia com espuma. Dr Charles Zarca é também pioneiro da escleroterapia com espuma e membro do Club-mousse.com também. O prof Jorge Segura é um dos pioneiros do ecodoppler, do laser e da escleroterapia com espuma na Argentina.

Estamos orgulhosos de poder contar com a participação de alguns colegas brasileiros importantes como Fanilda S. Barros, Francisco Maffei, Ivanésio Merlo, Jose Maria Godoy, Julio Ferreira, Kennedy Pacheco, Reginaldo Boppré, Roberto Kasuo Miyake e Walter Campos.

Teremos um curso de ecodoppler pré-simpósio que se dará no dia 21/03/2013 e depois os dias do SIF - 2013 com intensa programação.

Sabemos da necessidade de melhorar o atual quadro científico na flebologia, pois encontramos um numeroso conjunto de técnicas para o controle da IVC (Insuficiência Venosa Crônica) sem que até o momento não se possa dizer qual é o melhor deles. Há necessidade de serrar fileiras e procurar por trabalhos sérios e baseados em evidências científicas que nos guiem nossas escolhas.

Quem sabe no futuro poderemos melhorar nossos tratamentos, sejam cirúrgicos, endovenosos, físico ou químico?

Deveremos sim, cada vez mais, ter critérios científicos rigorosos, e escolher procedimentos próximos do ideal, que sejam seguros, eficazes, mais baratos, menos invasivos e que possam controlar todos os tipos de IVC.

É por isso tudo que se tornou imperativo registrar tudo o que acontecerá entre nós ou pelo menos um resumo de toda essa intensa programação científica. Pretendemos ter feito história na flebologia brasileira ao registrar nossas atividades.

Francisco Reis Bastos

Editor geral dos ANAIS DO SIF - 2013. www.flebologia2013.com.br

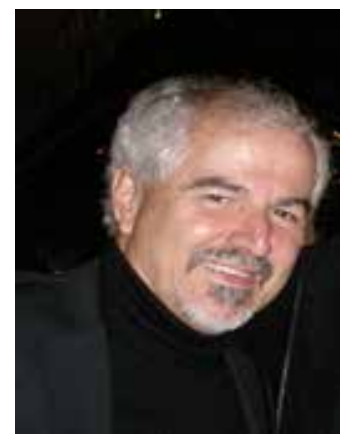

